\title{
The application of biomass ashes for improvement of sewage sludge dewatering
}

\author{
Marta Wójcik $^{1, *}$, Feliks Stachowicz ${ }^{1}$, and Adam Masłoń $^{2}$ \\ ${ }^{1}$ Rzeszow University of Technology, Department of Materials Forming and Processing, \\ 35-959 Rzeszow Al. Powstańców Warszawy 8, Poland \\ ${ }^{2}$ Rzeszow University of Technology, Department of Chemistry and Environmental Engineering, \\ 35-959 Rzeszow Al. Powstańców Warszawy 6, Poland
}

\begin{abstract}
In compliance with the requirements of the EU climate and energy package ( 3 x $20 \%)$, the biomass consumption in energetic industry is systematically growing. As a consequence, a large amount of ashes is produced which requires the management in line with law and ecology. Stringent requirements concerning the chemical composition of ashes prevent the biomass ash from being used in building construction. Specific physicochemical properties of ashes allow for their application in sewage sludge treatment. This paper presents the results of conditioning using ashes from willow combustion in sewage sludge dewatering. The findings could provide a new approach on sewage sludge and biomass ashes utilization.
\end{abstract}

\section{Introduction}

One of the main sources of atmosphere pollution is energetic industry. As a result of conventional fuel combustion, for example: coal, there are emitted gaseous air pollutants and ashes. The main chemical compounds which are produced during coal combustion are: carbon dioxide, carbon monoxide, $\mathrm{SO}_{\mathrm{x}}$ and $\mathrm{NO}_{\mathrm{x}}$. According to the requirements of $\mathrm{EU}$ climate and energy package $(3 \times 20 \%)$, renewable raw materials are used as a source of energy more and more often [1]. Biomass has a special importance amongst renewable energy sources. Currently, biomass energy comprises $8 \div 15 \%$ of the world energy supplies and it is expected to rise to $33-55 \%$ by 2050 [2]. In Poland, it is particularly used forest or agricultural biomass [3].

Biomass is a biodegradable fraction contained in municipal and agricultural waste. The biomass consumption is systematically growing in power stations and in electrical power and heating plants [3]. In Poland the biomass consumption was 9317763 GJ in coalburning power plants in 2005 [4]. For comparison, the use of biomass grew to 42917011 GJ in 2013. In 2013 the biomass consumption was 26275970 GJ in biomass-burning power plants [4]. It is also observed the increasing use of biomass and coal co-combustion. The main advantage of biomass combustion is "zero emission" of carbon dioxide. During the biomass burning, only so much carbon dioxide is emitted as a plant takes from the

*Corresponding author: m.wojcik@prz.edu.pl 
atmosphere by photosynthesis when the plants grow [5]. Additionally, the biomass combustion in incinerators causes a hazardous phenomenon concerning the forming of residue and the creating of sinters on heating surface of boilers. Moreover, the biomass contains corrosion components, such as potassium and sodium. Thus, biomass cocombustion is practised more often than the burning of $100 \%$ biomass [6].

The main sources of biomass for energetic industry in Poland are energetic crops, for example: straw and Salix viminalis. Due to the possibility of long term cultivation cycle, energetic plants are commonly used as a renewable energy source. The largest share of whole energetic plants has a willow tree. Rajczyk et al. [7] state that there are about 780 willow plant plantations with a surface area of 6480 ha, which contains about $95 \%$ of perennial plants cultivation.

Biomass is burnt in fluidized-bed incinerators in domestic power plants. The major problem associated with biomass combustion is the forming of combustion products, particularly ashes. Ash is the powdery residue produced as a result of burning of fuel that is captured from exhaust fumes means of electrostatic precipitators (fly ashes) or is discharged from fluidized bed (bottom ashes). According to Jarema-Suchorowska [8], approximately $4200 \mathrm{Mg}$ of biomass ashes were produced in Poland in 2012. Contrary to coal ashes, biomass combustion products are mainly stored. It is estimated that only $29.1 \%$ of biomass ashes were recycled in 2013 [8]. Recently, biomass ashes have been used in agriculture as a valuable fertilizer or in road construction [7]. The chemical composition (the content of chlorine and alkalis) and high losses of ignition lead to the fact that most of biomass ashes fail to fulfill standard requirements as a component of cement and concrete production. According to PN-EN 197-1:2012 and PN-EN 450-1:2012, ashes with the chlorine content below $0.1 \%$ and with high loss of ignition $(>5 \%)$ could not be used in production of building materials $[9,10]$. Furthermore, the addition of ashes from biomass combustion negatively affects pozzolatic activity index. The application of biomass ashes in mining is also restricted due to exceding the limits of $\mathrm{pH}$, chloride and suplhate leaching, which are determined in PN-G-11011 [4].

The requirements in economic sectors prevent biomass ashes from recycling. For this reason, there have developed new ashes utilization methods. Due to specific sorptive properties, ashes from biomass combustion could be managed in sewage sludge treatment. The addition of biomass ashes influences morphologicfal characteristics of sewage sludge. Sewage sluge has a negative charge and creates a stable system with low-sediment and lowdewatering capacity. After the conditioning with application of biomass ashes, sewage sludge is neutralized and the particles are fused together to from larger flocs [11]. According to Masłoń [12], powder materials below $300 \mu \mathrm{m}$ diameter are incorporated in floc structure and become a weight of sludge that could improve the sludge settleability and dewatering. This paper presents the results of sewage sludge conditioning with ashes from willow combustion. The findings could provide a new approach for sewage sludge and biomass ashes utilization.

\section{Materials and methods}

Sewage sludge used in laboratory tests was obtained from the thickening tank from Municipal Wastewater Treatment Plant in Świlcza in the Podkarpacie region. In this study, sewage sludge was taken during summer/autumn and was characterized by grey-brown colour and earthy smell. The detailed physical and chemical properties of raw sewage sludge are presented in the Table 1. 
Table 1. The physical and chemical properties of raw sewage sludge.

\begin{tabular}{|c|c|}
\hline Parameter & Value \\
\hline $\mathrm{pH}$ & 6.65 \\
\hline water content [\%] & 96.83 \\
\hline dry mass [\%] & 3.17 \\
\hline concentration of dry mass [g d.m./. $\left.\mathrm{dm}^{3}\right]$ & 31.70 \\
\hline CST (capillary suction time) $[\mathrm{s}]$ & 149.21 \\
\hline
\end{tabular}

In laboratory research, ash from willow combustion in domestic incinerator was used. The willow tree, from which ash was obtained, derived from a small agricultural business, in Wielkopolska region. The granulometric analysis was performed by means of the laser diffraction method. To determine particle size distribution of ash, Malvern Mastersizer 2000 particle size analyser was used. The willow ash was characterized by particles in the range of $0.399-900 \mu \mathrm{m}$ (Fig.1). Due to the fact that ash was not sieved before laboratory tests, there were some coarse particles in material. The detailed grain size properties of ash from willow trees combustion are presented in Table 2. The results of diffraction analysis XRD show that ash comprises the following oxides: $\mathrm{SiO}_{2}, \mathrm{MgO}, \mathrm{CaO}, \mathrm{Al}_{2} \mathrm{O}_{3}, \mathrm{Fe}_{2} \mathrm{O}_{3}, \mathrm{NaO}_{2}$, $\mathrm{Na}_{2} \mathrm{O}, \mathrm{KO}_{2}$. SEM images of ash from willow combustion are shown in Fig. 2.

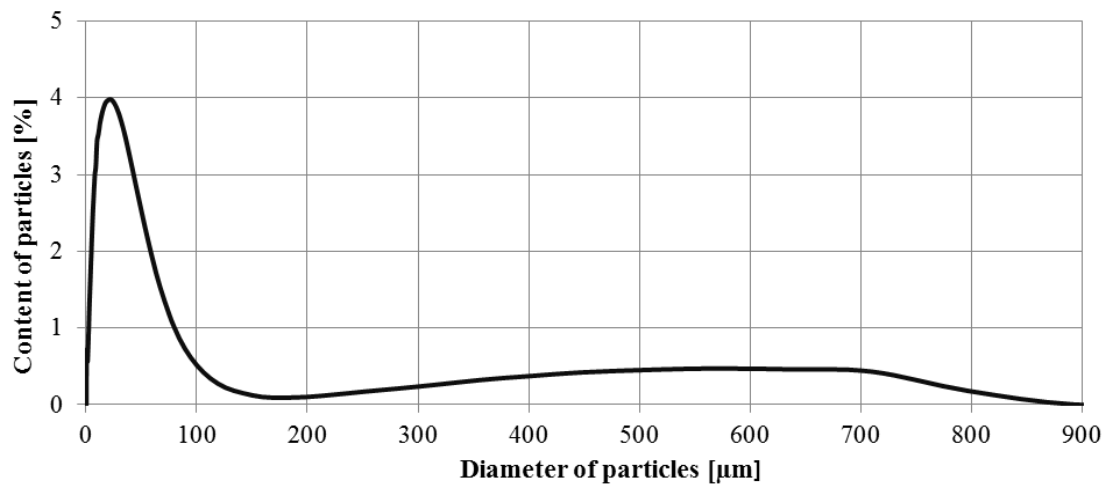

Fig. 1. The granulometric analysis of willow ash.
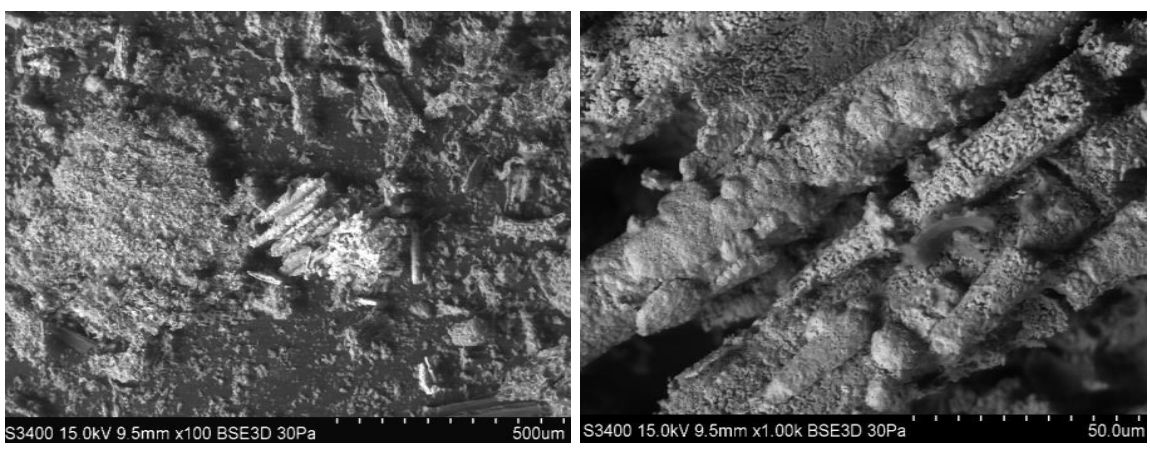

Fig. 2. SEM images of willow ash. 
Table 2. The grain size properties of ash from willow combustion.

\begin{tabular}{|c|c|}
\hline Parameter & Value \\
\hline $\mathrm{d}_{10}[\mu \mathrm{m}]$ & 2.636 \\
\hline $\mathrm{d}_{50}[\mu \mathrm{m}]$ & 16.727 \\
\hline $\mathrm{d}_{90}[\mu \mathrm{m}]$ & 64.314 \\
\hline $\mathrm{SMD}$ (Surface Mean Diameter) $[\mu \mathrm{m}]$ & 5.896 \\
\hline VMD (Volume Mean Diameter) $[\mu \mathrm{m}]$ & 45.092 \\
\hline $\mathrm{C}_{\mathrm{u}}$ (Uniformity coefficient) $[-]$ & 7.580 \\
\hline $\mathrm{C}_{\mathrm{c}}$ (Coefficient of curvature) $[-]$ & 1.149 \\
\hline
\end{tabular}

Laboratory tests of sewage sludge conditioning and dewatering with application of willow ash were carried out in three series. The sewage sludge conditioning with ashes was carried out as follows: five beakers with a volume of $1 \mathrm{dm}^{3}$ were filled with $500 \mathrm{~cm}^{3}$ of raw sewage sludge. The appropriate dosages of ash $\left(5 ; 7.5 ; 15\right.$ and $\left.30 \mathrm{~g} / \mathrm{dm}^{3}\right)$ were added to four beakers. The dosages could be expressed as the weight ratio of ash to sewage sludge dry mass: $170 \mathrm{~g} / \mathrm{kg}$ d.m.; $250 \mathrm{~g} / \mathrm{kg}$ d.m.; $500 \mathrm{~g} / \mathrm{kg}$ d.m. and $1000 \mathrm{~g} / \mathrm{kg} \mathrm{d.m.,} \mathrm{respectively.}$ Firstly, mixtures were rapidly stirred with a speed of $200 \mathrm{rpm}$ for 1 minute and after that, they were stirred with a speed of $50 \mathrm{rpm}$ for 15 minutes. In sewage sludge after conditioning, $\mathrm{pH}$ and capillary suction time (CST) were determined. The effectiveness of sewage sludge conditioning with willow ash has been determined by comparing the results for raw sludge.

Then, for prepared samples of sewage sludge, the dewatering capacity was investigated. Mechanical dewatering process was done in a Büchner funnel and in a centrifuge. The sewage sludge dewatering was carried out as follows: $50 \mathrm{~cm}^{3}$ of sewage sludge was poured into a Büchner funnel. The process was done under 0.01 and $0.02 \mathrm{MPa}$ vacuum pressure for about 15 minutes. Centrifugation of sewage sludge was conducted for two rotation speeds: 2000 and $2500 \mathrm{rpm}$ for 5 minutes. After mechanical dewatering, the moisture content and CST were determined according to PN-EN 15934:2013-02. CST was measured using CST meter (ProLabTech) in accordance with PN-EN 147011:2007. In the conditioned sewage sludge, the $\mathrm{pH}$ was analyzed with $\mathrm{pH}-$ meter HACH HQ40d according to PN-EN 15933:2013-02.

\section{Results and discussion}

Firstly, ash from willow combustion was used as a conditioner. Research has shown that the sewage sludge conditioning with biomass ash influenced the improvement of sewage sludge dewatering. The evaluation of conditioning effectiveness (Fig. 3) was done by means of CST measurement. CST of raw sewage sludge was $149.21 \mathrm{~s}$ and CST after conditioning with the ash in dosage of $30 \mathrm{~g} / \mathrm{dm}^{3}$ was $66.77 \mathrm{~s}$. The application of ash from willow combustion has resulted in the decline of CST in the whole range of agent used. However, low dosages did not influence the decrease of CST significantly. The best result was achieved for a dose of $30 \mathrm{~g} / \mathrm{dm}^{3}$ and for this reason, this amount of ash was considered 
as an optimal dosage. For the dosage of $30 \mathrm{~g} / \mathrm{dm}^{3}$, CST was $55.25 \%$ lower than for nonconditioned sewage sludge. In comparison with commonly used polyelectrolytes, ash is a less effective reagent. Research conducted by Piotrowska-Cyplik and Czarnecki [13] has shown that the application of cationic polyelectrolyte F-410 in optimal dosage reduced the CST value of about $80 \%$ (from $70 \mathrm{~s}$ to $14 \mathrm{~s}$ ).

Biomass ashes could be an effective reagent in sewage sludge hygienisation. The influence of ash from willow combustion on the growth of $\mathrm{pH}$ was shown in Fig. 4 - $\mathrm{pH}$ for raw sewage sludge was 6.67 and for sewage sludge after the addition of ash in dosage of $30 \mathrm{~g} / \mathrm{dm}^{3}$ was 9.92. Wang and Viraraghavan [14] reported approximate results of the growth of $\mathrm{pH}$ for coal fly in fly ash to sewage sludge ratio 1:1 (the growth of $\mathrm{pH}$ from 7.25 to 10.32). The positive impact of ash on the $\mathrm{pH}$ is connected with the content of alkaline metals in ash, for example: $\mathrm{Ca}, \mathrm{Mg}$ and $\mathrm{Na}$, what is acknowledged by the literature review $[13,15]$. $\mathrm{pH}$ of sewage sludge is one of the major factors that have an influence on the pathogens reduction. According to Marcinkowski [16], most of pathogens are killed at $\mathrm{pH}>9$ and for this reason, ash from willow combustion could be an effective reagent in sewage sludge hygienisation. It is worth highlighting that biomass ash is less efficient than burnt lime. Own research shown that the dosage of $\mathrm{CaO}$ in the amount of $1 \mathrm{~kg} / 1 \mathrm{~kg}$ dry mass increased $\mathrm{pH}$ of sewage sludge from 6.60 to 13.48 .

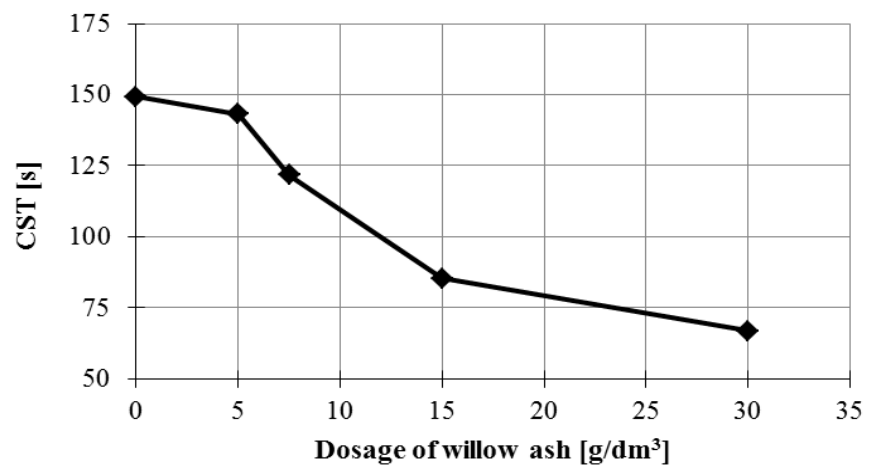

Fig. 3. The influence of sewage sludge conditioning with willow ash on CST.

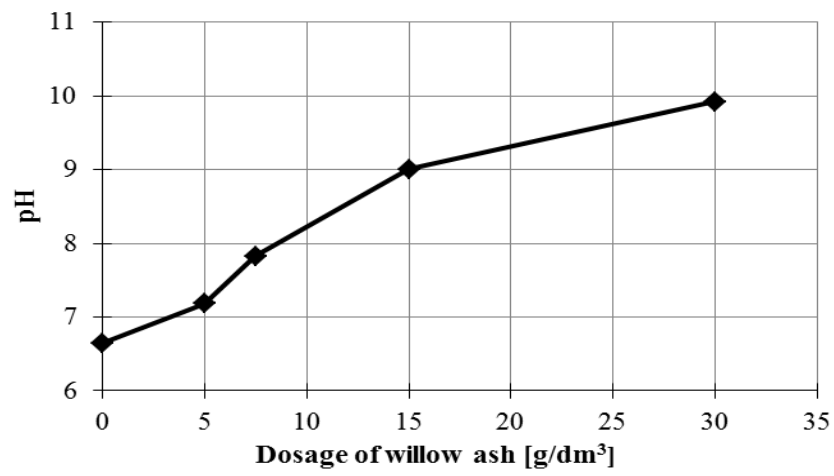

Fig. 4. The influence of willow ash on $\mathrm{pH}$ of sewage sludge.

In order to determine the effectiveness of sewage sludge conditioning with biomass ash, conditioned sludge was dewatered with use of Büchner filter and the centrifuge. The effectiveness of dewatering has been determined by comparing the results for raw sewage sludge. The measure of effectiveness was moisture content and CST after dewatering.

Firstly, sewage sludge was investigated using of centrifuge. The moisture content of sewage sludge for two rotation speeds: 2000 and $2500 \mathrm{rpm}$ is shown in Fig. 5. The content 
of water in sewage sludge decreased with an increase of dosage of ash. With the $30 \mathrm{~g} / \mathrm{dm}^{3}$ dosage of ash, the moisture content decreased from $92.92 \%$ (raw sewage sludge) to $85.77 \%$ (conditioned sewage sludge) for the rotation speed of $2000 \mathrm{rpm}$. Better results were obtained for higher rotation speed. The application of $30 \mathrm{~g} / \mathrm{dm}^{3}$ dosage of ash from willow combustion reduced the moisture content from $91.80 \%$ (raw sludge) to $84.31 \%$ (conditioned sludge). Low dosages did not reduce the moisture content in a significant way.

CST increased with the rise of dosage of ash. It was observed that CST depends on the sewage sludge moisture content. The higher value of CST could mean that sewage sludge has a more consistent structure. The elimination of excessive water, it is resistant to further dewatering. Higher values of CST were obtained for the rotation speed of $2500 \mathrm{rpm}$ what is connected with the better effectiveness of centrifugation (Fig. 6).

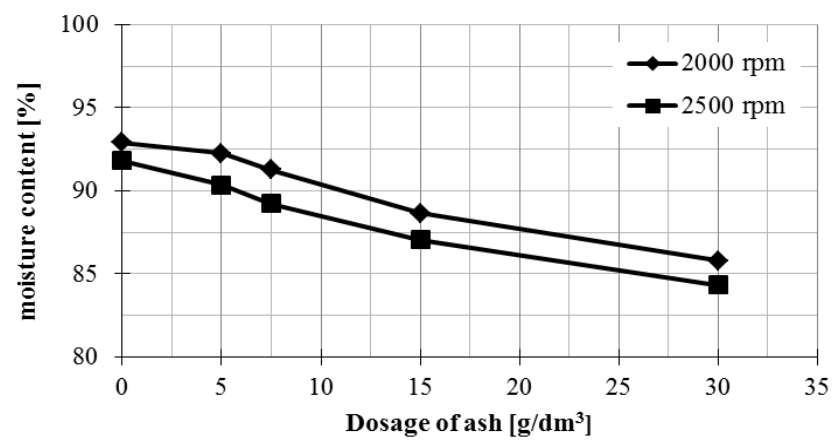

Fig. 5. The influence of willow ash on moisture content after centrifugation.

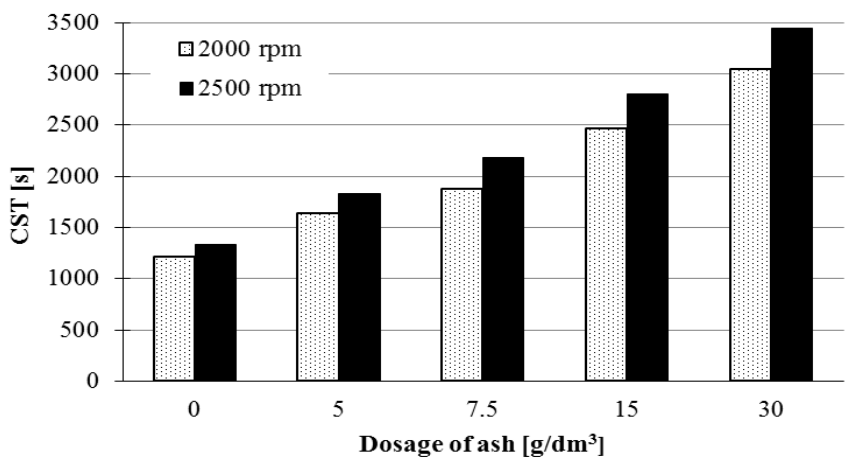

Fig. 6. The influence of willow ash on CST after centrifugation.

The best results of sewage sludge dewatering were obtained for vacuum filtration with Büchner funnel. The filter cake moisture for different dosages of ash after dewatering is presented in Fig. 7. The analysis of the results shows that raw sewage sludge indicated a good susceptibility to dewatering. The filter cake moisture for raw sewage sludge was respectively $89.72 \%$ for $0.01 \mathrm{MPa}$ vacuum pressure and $88.47 \%$ for $0.02 \mathrm{MPa}$ vacuum pressure. The sewage sludge content of moisture decreased as the dosage of ash and the vacuum pressure increased. With the $30 \mathrm{~g} / \mathrm{dm}^{3}$ dosage of willow ash, the filter cake moisture content decreased to $78.61 \%(0.01 \mathrm{MPa})$ and to $75.80 \%(0.02 \mathrm{MPa})$. It is worth highlighting that for the vacuum filtration process, the application of ash is effective in a whole range of doses. Similar results of dewatering were obtained by Bień [17] for average cationic polyelectrolyte. Increasing both willow ash dosage and the vacuum pressure causes an increase of CST (Fig.8). In comparison with the results for 
centrifugation, CST was approximately $48 \%$ higher. The higher value of CST is a result of the better effectiveness of sewage sludge dewatering in vacuum filtration.

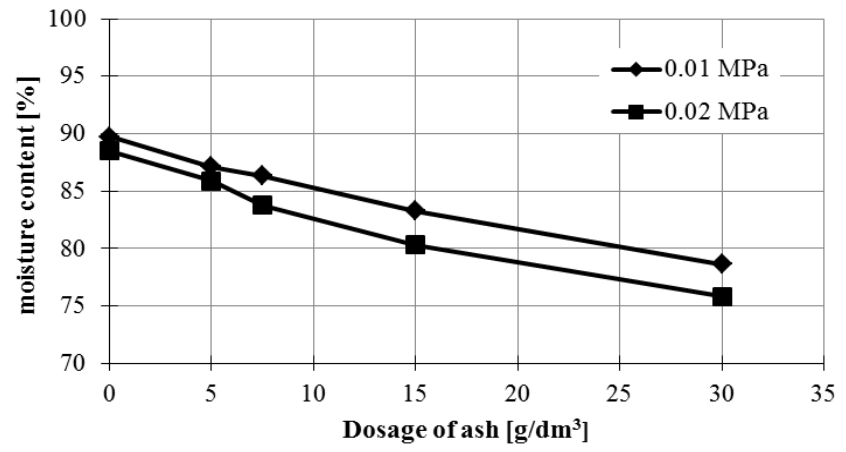

Fig. 7. The influence of willow ash on moisture content after vacuum filtration process.

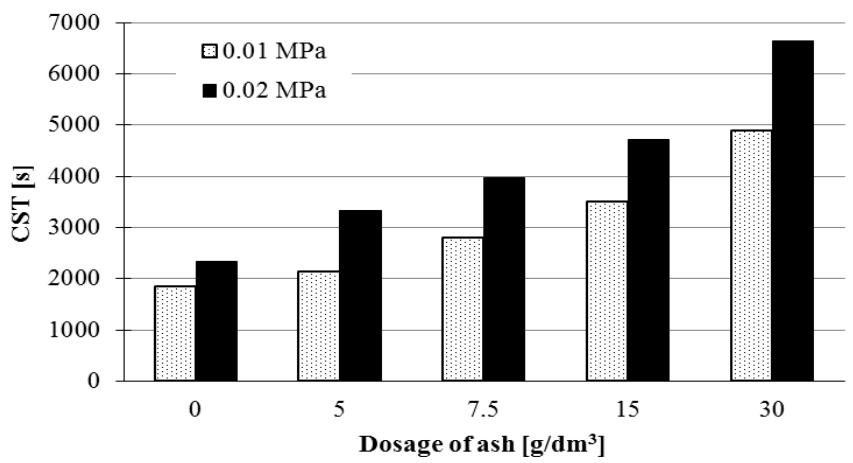

Fig. 8. The influence of willow ash on CST after vacuum filtration process.

\section{Summary}

The increase in the share of renewable energy in final energy production is associated with the biomass combustion. Biomass fuel is very attractive from the ecological point of view in terms of "zero-emission" of carbon dioxide. During the biomass combustion, there are produced combustion products, such as bottom and fly ashes. Stringent requirements prevent biomass ashes from being used as a component in concrete and cement production. For this reason, biomass ashes are mainly stored.

This study proved that biomass ash could improve sewage sludge dewatering. To evaluate the efficiency of sewage sludge dewatering, the following parameters were used: moisture content and CSK. The obtained results of laboratory tests allow us to draw the following conclusions:

1. The application of willow ash had a positive impact on sewage sludge dewatering what is confirmed by the measurement of CST. This parameter decreases with the increase of dosage of ash.

2. The analysis of results has shown that the addition of willow ash could improve the capacity of sewage sludge dewatering. The application of higher doses of ashes yielded better results which are confirmed by CST and moisture content after dewatering. The best results of sewage sludge dewatering were obtained for vacuum filtration and for 
dose of ash of $30 \mathrm{~g} / \mathrm{dm}^{3}$. The addition of low dosages of ash from willow could slightly improve the sewage sludge dewatering.

3. The application of willow ash might raise $\mathrm{pH}$ of conditioned sewage sludge. For this reason, it is possible to reduce the amount of pathogens and achieve the partial hygienisation of sewage sludge.

The confirmation of the effectiveness of biomass ashes in sewage sludge conditioning might reduce the consumption of polyelectrolytes and contribute to the reduction of operating costs of treatment plants. After dewatering, sewage sludge containing ash may be considered as a valuable fertilizer in perennial plantations, creating a closed circuit. Due to the application of sewage sludge in energetic plant plantations, heavy metals in sewage sludge do not affect human health [18].

\section{References}

1. Law on Renewable Sources of Energy Adopted on 20 February 2015. Journal of Laws, Item 478 (2015)

2. S.V. Vassilev, D. Baxter, L.K. Andersen, C.G. Vassileva, Fuel 105, 41 (2013)

3. D. Fijałkowska, L. Styszko, Annual Set the Environment Protection 13, 875 (2011)

4. A. Uliasz-Bocheńczuk, A. Pawluk, J. Skierka, Mineral Resources Management 31, 145 (2015)

5. T. Czech, A.T. Sobczyk, A. Jaworek, A. Krupa, Conference Materials POL-EMIS, June 2012

6. W. Mokrosz, MOKROSZ Sp. z o.o., Politechnika Śląska 2014

7. K. Rajczyk, E. Giergiczny, M. Szota, Scientific Works of Institute of Ceramics and Building Materials 6, 73 (2013)

8. [online] [access: 10.12.2016] https.://www.kierunekenergetyka.pl/magazyn, popioły-zbiomasy.html

9. PN-EN 197-1:2012, Cement - Part 1: Composition, specifications and conformity criteria for common cements

10. PN-EN 450-1:2012, Fly Ash For Concrete - Part 1: Definition, Specifications And Conformity Criteria

11. P. Zhang, L. Haifeng, The Chemical Engineering Journal 156, 620 (2010)

12. A. Masłoń, Instal 4, 51 (2015).

13. A. Piotrowska-Cyplik, Z. Czarnecki, Journal of Research and Applications in Agricultural Engineering 50, 23 (2005)

14. S. Wang, T. Viraraghavan, Waste Management 17, 447 (1997)

15. A. Kowalczyk-Juśko, Proceedings of EC Opole 3, 159 (2009)

16. T. Marcinkowski, Environmental Pollution Control 25, 49 (2003)

17. J. Bień, Engineering and Protection of Environment 14, 329 (2011)

18. F. Stachowicz, T. Trzepieciński, M. Wójcik, A. Masłoń, W. Niemiec, A. Piech, E3S Web Conf. 10, 1 (2016) 